\title{
Factors determining the adoption and impact of a postharvest storage technology
}

\author{
Raushan Bokusheva $\cdot$ Robert Finger $\cdot$ Martin Fischler • \\ Robert Berlin • Yuri Marín • Francisco Pérez • \\ Francisco Paiz
}

Received: 18 October 2011 / Accepted: 21 March 2012 /Published online: 20 April 2012

(C) The Author(s) 2012. This article is published with open access at Springerlink.com

\begin{abstract}
This paper evaluates the determinants and impact of adopting the metal silo- a postharvest storage technology for staple grains - which was disseminated by the Swiss Agency for Development and Cooperation (SDC) from 1983 to 2003 in four Central American countries. The aim of the SDC program was to diminish smallholder farmers' postharvest losses by facilitating the manufacture and dissemination of metal silos and thereby to improve regional food security. Our empirical analysis is based on a unique data set obtained from a survey of 1,600 households from El Salvador, Guatemala, Honduras and Nicaragua. We employed a double-hurdle model to identify factors that contributed to the adoption of metal silos and used Tobit and standard regression models to assess the impact of adopting the silos on food security and well-being of households. Our results show that both the household demand for metal silos and the impact of their adoption varied across the four countries, demonstrating the relevance of regional policies for their adoption, as well as their impact. Furthermore, our results indicate that, in addition to achieving household
\end{abstract}

R. Bokusheva $(\bowtie) \cdot$ R. Finger

Swiss Federal Institute of Technology ETH Zurich,

Zurich, Switzerland

e-mail: bokushev@ethz.ch

M. Fischler

HELVETAS Swiss Intercooperation,

Bern, Switzerland

R. Berlin

Syngenta Foundation for Sustainable Agriculture,

Basel, Switzerland

Y. Marín · F. Pérez · F. Paiz

Institute of Applied Research and Local Development (Nitlapan),

Central American University (UCA),

Managua, Nicaragua self-sufficiency in maize, the main determinants of adoption were household socio-economic characteristics such as age, land ownership, completion of a training course and quality of basic infrastructure. Finally, when considering a group of economic and social indicators of household well-being, we found that, compared to the silo non-adopters, the adopter households experienced a significant improvement in their food security and well-being between 2005 and 2009.

Keywords Food security · Impact assessment · Investment decision · Postharvest grain losses · Central America

\section{Introduction}

Approximately 16 million people, or $47 \%$ of the total population of Guatemala, El Salvador, Honduras and Nicaragua, still live in rural areas (World Bank 2008). Of this population, $62 \%$, i.e. ca. 10 million people, are producers of staple grains (i.e. maize, beans, rice and sorghum) (Baumeister 2010). The majority of staple grain producers are small to mediumsized family farms. Between $39 \%$ (Nicaragua) and $92 \%$ (Guatemala) of staple grain producers in the abovementioned countries possess less than 2.1 ha (which corresponds to 3 "manzanas"1) of land (Baumeister 2010). Poverty (defined as not having sufficient means to cover basic needs) is widespread for rural staple grain producer families, ranging from $56 \%$ in El Salvador to $91 \%$ in Honduras (Baumeister 2010).

Staple grains, primarily maize and beans, play crucial roles in food security and income generation, as well as the livelihoods of rural inhabitants of Central America.

\footnotetext{
${ }^{1}$ Manzana is the local land measurement unit. One manzana is equal to approx. 0.7 hectare.
} 
Maize is the main staple food and beans are an important additional source of protein that complements the maizebased diet. While white maize is mainly used for human consumption, yellow maize is primarily used as fodder. Annual food requirements of a household with an average size of 5.4 persons amounts to about $810 \mathrm{~kg}$ of maize and $240 \mathrm{~kg}$ of beans (Baumeister 2010).

Postharvest damage (i.e. physical alteration caused by biotic or abiotic agents) and loss (i.e. the difference between totally damaged and recoverably damaged grain still fit for human consumption) of staple grains due to insect pests, rodents and birds are common problems in developing countries. However, precise information on postharvest losses of maize and beans in Central America is scarce. A two-year study (production cycles 1980-81 and 1981-1982) conducted in Honduras by Raboud et al. (1984) found that postharvest damage and losses of stored maize amounted to $12.5 \%$ and $8.1 \%$, respectively (averaged for the two study years). Similarly, Abeleira et al. (2008) found postharvest bean losses in Mexico were 10\%.

Given the importance of postharvest management of staple grains in Central America, the program "Postcosecha" ("postharvest" in Spanish) was launched in 1983 by the Swiss Agency for Development and Cooperation (SDC) in Honduras. Later, the program was extended to Guatemala (1990), Nicaragua (1992) and El Salvador (1994). The program consisted of the production and dissemination of metal bins (silos) for the postharvest storage of staple grains. Between 1983 and 2009, almost 670,000 metal silos were produced and disseminated in Central America (SDC 2011). This postharvest technology was developed for the storage of maize and, to a more limited extent, beans. Currently, more than 400,000 mostly rural households, i.e. approximately 2.4 million rural people in Honduras, Guatemala, Nicaragua and El Salvador, use the metal silo for grain storage (Table 1); this number represents $24 \%$ of the rural households producing staple grains. Table 1 shows that $46 \%$ of the metal silos were disseminated after the direct support by SDC ended in 2003 (SDC 2011), which confirms a successful continuation of the program, particularly in the case of Guatemala.

The means by which metal silos were disseminated after 2003 have evolved differently in the four countries and need to be considered in order to explain the pattern of silo adoption in each country. Most farmers purchase their silos directly from tinsmiths or through a governmental program, or through non-governmental organizations (NGOs). In Honduras, the main means of acquisition was direct purchase from tinsmiths (86\%). In Nicaragua, besides direct purchase from tinsmiths (57\%), acquisition was through NGOs $(23 \%)$. To increase food security in rural areas, the Guatemalan government introduced a large subsidy program in 2000, targeting poor rural families; the program subsidizes $62 \%$ of the fixed selling price of 58 USD (as of 2009) for a 12 quintal $(545 \mathrm{~kg}$ ) silo by providing the
Table 1 Adoption of plain metal silo for grain storage according to countries and periods

\begin{tabular}{lllll}
\hline Country & \multicolumn{2}{l}{$\begin{array}{l}\text { Number of metal silos } \\
\text { disseminated }\end{array}$} & $\begin{array}{l}\text { Number of } \\
\text { households using } \\
\text { silos in 2009 }\end{array}$ \\
\cline { 2 - 4 } & $\begin{array}{l}1983- \\
2003\end{array}$ & $2004-$ & Total & \\
& 2009 & $1983-2009$ & \\
\hline $\begin{array}{c}\text { Honduras } \\
(1983)^{\mathrm{a}}\end{array}$ & 147,427 & 81,381 & 228,808 & 133,850 \\
$\begin{array}{c}\text { Guatemala } \\
(1990)^{\mathrm{a}}\end{array}$ & 103,374 & 137,994 & 241,368 & 158,430 \\
$\begin{array}{c}\text { Nicaragua } \\
(1992)^{\mathrm{a}}\end{array}$ & 59,618 & 60,785 & 120,403 & 68,710 \\
$\begin{array}{c}\text { El Salvador } \\
(1994)^{\mathrm{a}}\end{array}$ & 46,190 & 30,188 & 76,378 & 52,880 \\
\begin{tabular}{c} 
Total \\
\hline
\end{tabular} & 357,339 & 310,348 & 667,687 & 413,870 \\
\hline
\end{tabular}

${ }^{a}$ Refers to the official start of the Postcosecha Program by SDC. Some pilot activities producing a small number of metal silos occurred beforehand. Official support by SDC ended in December 2003. ${ }^{\mathrm{b}}$ assessed considering: a) the number of the metal silos used per household; and b) a lifespan of 15 years for the metal silo.

Source: SDC 2011

galvanized iron sheets to the contracted tinsmiths. Approximately $75 \%$ of the disseminated metal silos fall under the subsidy program, which explains the large increase of disseminated metal silos in recent years. In El Salvador, about $54 \%$ of the metal silos were handed over to farmers either as donations (mostly through NGOs), or "in concession", which implies that the farmer obtains the silo free as part of an agricultural subsidy package that included seeds, fertilizer and other relevant materials. However, the silo remained government property and the farmer was not allowed to sell the silo.

A metal silo is a cylindrical structure (one standard design), constructed from high quality galvanized iron sheet (gauge No. 26 or 24) with a top inlet and a smaller lateral outlet at the bottom. The silos are locally constructed by trained artisanal tinsmiths with simple tools (for detailed descriptions and procedures how to fabricate the metal silo see SDC 2008a and Bravo 2009. Metal silos generally hold between 100 and $3000 \mathrm{~kg}$ of grain. Rural families in Central America most commonly use either the 12 quintal $^{2}(545 \mathrm{~kg})$ or 18 quintal $(820 \mathrm{~kg})$ size, corresponding to the annual grain consumption of an average family of 5-6 persons. The metal silo can be hermetically sealed, allowing farmers to fumigate the stored grain by using pellets containing phosphine compounds (e.g. aluminum phosphide, "phostoxin" (Bravo 2009)). An important aspect is that the grain must be properly dried (maximum of $13 \%$ moisture content) before filling the silo in order to avoid moulds. The metal

\footnotetext{
$\overline{21 \text { quintal (qq.) }}=45.45 \mathrm{~kg}$
} 
silo technology has proved to be effective in protecting harvested grains from attack, not only from storage insects but also from rodent pests, birds, insects, and fungal invasion (moulds) (SDC 2008b; Tefera et al. 2010). Users of the metal silos indicated that they were more effective in the control of postharvest losses than traditional storage methods such as granaries, barns, sacks, and metal and plastic barrels (Hermann 1991; Coulter et al. 1995; Gladstone et al. 2002). The objectives of the metal silo dissemination program were to improve the food security and livelihoods of poor rural households and to create employment and income for artisanal tinsmiths who produce the silos (SDC 2008b; Tefera et al. 2010).

There are several socio-economic studies that evaluate the Postcosecha Program which consider such aspects as food security, livelihoods and maize buying and selling, including price dynamics. According to the study by Raboud et al. (1984), metal silos reduce storage losses to less than $1 \%$, compared to an average of $10 \%$ in conventional maize facilities. Considering the dissemination dynamics of the metal silos since 1983 (Table 1), SDC (2011) estimated that the accumulated grain saved from potential postharvest loss in the four considered countries accounted for up to 336,000 tons during the last 27 years. In 2009, the total storage capacity of metal silos in all four countries reached approximately 380,000 tons (SDC 2011); this means that about 34,000 tons (9\%) were saved annually from potential storage losses, equivalent to the food requirement for almost 45,000 families.

For a group of farms $(N=60)$ in Honduras, Hermann (1991) reports that $20 \%$ of the surveyed farmers were metal silo users. Of the non-users, $83 \%$ indicated they would not have enough stored grains (maize, beans) to cover their food needs until the next harvest. The silo users said that they bought maize mainly during periods of low prices, whereas the non-users needed to buy mostly during the high price period from May to July. Coulter et al. (1995) report that due to the use of the metal silos, farmers stored more grain than previously (study conducted in El Salvador, Guatemala, Honduras and Nicaragua). Gladstone et al. (2002) found that among the farms surveyed in their study, $60 \%$ of the users still had some maize stored in the metal silo by the time of the new harvest compared to $29 \%$ of the non-users. All the above mentioned studies concluded that the use of metal silos has increased the food security of poor rural households.

Besides increasing food security, it is expected that farmers would gain flexibility in deciding when to sell the safely stored grain by taking advantage of seasonal price fluctuations caused by changes in supply and demand (Florkowski and Xi-Ling 1990). In Central America, prices are usually low during postharvest months (mid-August to February) when the supply is high, and peaks before the next harvest (from May until the beginning of August) when the grain available in the market becomes more scarce (Zappacosta 2005; Hernández 2008; Pérez et al. 2010). However, these recurring seasonal trends have also been distorted in Central America since 2007 due to the food price crisis (Pérez et al. 2010).

Hermann (1991) found that $67 \%$ and $40 \%$ of users and nonusers of metal silos surveyed in Honduras sell maize. The users reported selling $66 \%$ of the stored maize before the new harvest during the high price period from May to August at an average price of $8.85 \mathrm{USD} /$ quintal. The non-users stated they sold $50 \%$ shortly after harvest, i.e. from November to December, at an average price of 7.00 USD/quintal, but the rest was sold more evenly throughout the year. Additionally, the users reported selling $74 \%$ of the total maize to relatives or within the village, whereas the non-users were selling the bulk $(87 \%)$ of their maize to intermediates or in the market. Coulter et al. (1995) found that the silo users have more freedom to sell maize when prices are higher and to sell more within the community, thereby reducing dependence on intermediates. In addition, Gladstone et al. (2002) reported that in their study, $67 \%$ of the women silo users reported having more opportunities to sell any desired quantity of the stored maize at their convenience to cover household costs.

The abovementioned socio-economic studies state that the use of the metal silo also has had a positive effect on the livelihoods of the families considering such aspects as food security, workload, hygiene and health. Hermann (1991) found that $50 \%$ of the silo users surveyed in Honduras indicated that they had a more balanced diet, i.e. the family consumed more rice, beans, meat, eggs, milk and milk products than prior to their use of the metal silo.

Another important aspect is related to a change in the postharvest workload of the family. The need to shell and remove the maize grain from the cob in order to fill the metal silo at one time involves considerable labor, which may be hired, or the use of mechanized equipment if available. However, the stored grain is ready for consumption and therefore there is no need for daily shelling and removal of grains from the cob, work which is mostly done by women when a household uses a traditional storage system. Consequently, $77 \%$ of the women in the surveyed households, who were users of silos, confirmed that their workload in postharvest operations had declined (Gladstone et al. 2002).

Finally, in the study by Hermann (1991) $93 \%$ of the silousers indicated that their houses were cleaner than they were before silo adoption on account of fewer insect pests and rodents and therefore less spoilage. Better nutrition and hygiene also had a positive effect on health (especially that of children). Moreover, farmers indicated that they had fewer risks and health problems using aluminum phosphine in a hermetically sealed metal silo than when applying other storage pesticides in traditional storage systems (Gladstone et al. 2002)

All the above-mentioned studies were conducted during the implementation phase of the Postcosecha Program and thus provide an interim evaluation of the program's impact. In the present study we aim to give an ex-post assessment of 
the program's impact. In particular, the present study's objectives are: (i) to identify factors that significantly contributed to the adoption of the metal silo in the four countries; and (ii) to assess the impact of adoption of metal silos on the food security and well-being of rural households. In order to do this a household survey and an examination of existing secondary data on the number of disseminated silos was conducted in 2009. Based on the survey data, this paper presents an in-depth analysis of selected aspects pertaining to the effect of metal silo adoption on food security, well-being and grainselling dynamics of staple grain producing households.

The remainder of the paper is organized as follows. Section 2 describes the methodology and the data employed to analyze factors relevant to the adoption of the technology and the effect of adoption on household food security and well-being. Section 3 presents the results and Section 4 draws conclusions and presents policy implications.

\section{Materials and methods}

\section{Materials}

The study utilizes data from a survey conducted with 800 non-users and 800 users of metal silos. Each of the four countries considered was represented by 200 users and 200 non-users. However, after calibrating the data, the initial sample size was reduced to 1,535 households.

The selection of the interviewed households was carried out by applying a random sampling procedure with multistage cluster sampling. The main selection criteria were the following: farms have (i) to be situated in one of the main maize-producing zones in each of the four countries; (ii) to belong to the farmer and be small or medium-sized maize farms with up to 15 manzanas (i.e. 10.5 hectares) (iii) to produce and store primarily maize grain (in metal silos or by other storage methods).

The structured interview with the surveyed households considered the following aspects ${ }^{3}$ :

- basic individual characteristics such as, for example, household owner's gender, age, education level, and family size.

- production-related characteristics, e.g. area of owned and rented land, amounts of maize and beans production, number of hired workers, number of livestock, access to advisory services and credit.

- postharvest management characteristics, i.e. date of acquisition of the metal silo and size, storage and use of grain from different storage systems, beans and maize sales and prices.

\footnotetext{
${ }^{3}$ The complete questionnaire is available upon request.
}

- impact indicators: income and employment, investments, food security and livelihoods.

To assess the impact of adopting the metal silo, we focus on subsistence farms, i.e. small farms producing maize primarily for consumption by the farmer's family. We define subsistence farms by selecting farms for which maize production does not exceed maize consumption by a factor of $3 .^{4}$ As a result, the number of sample farms was further reduced to a total of 1,195 farms for this part of the analysis.

The same (reduced) dataset was used to analyze determinants of the household decision to invest in a metal silo. ${ }^{5}$ However, in the adoption analysis, we selected only those user-households that invested in a metal silo for the first time between 2005 and 2009. This selection was dictated mainly by the availability of data. ${ }^{6}$ Moreover, this time span refers to the period after 2003 when the SDC had stopped providing direct support to the Postcosecha Program in all four countries. An additional selection criterion for households used in the adoption analysis was that the farmers had paid at least a part of the metal silo market price. This criterion reduced the number of user-households to a total of 179: there were101 in Guatemala, 43 in Honduras, 21 in Nicaragua and 14 in El Salvador. The sample of 528 non-user-households consists of 141, 169, 92 and 126 households from Guatemala, Honduras, Nicaragua and El Salvador, respectively. Regarding the low number of the user-households for El Salvador and their small share compared to non-user households, we decided not to consider them further in the analysis.

\section{Methods}

\section{Investment decision model}

To explain a household's investment in metal silos, we employed a model which considers the investment decision

\footnotetext{
${ }^{4}$ This ratio was calculated based on the farm maize production and consumption data for 2008, which was more representative than 2009 considering weather conditions for grain production. We employed a relatively high upper limit of this indicator to consider that in bad harvest years maize production might drop substantially and thus seriously affect farm food security.

${ }^{5}$ We excluded from the sample farms with higher levels of selfsufficiency (i.e. maize production exceeds family consumption by three times), as the focus of our analysis is on small subsistence households. Additionally, considering that the adoption of metal silos might have been influenced for commercially-oriented farms by factors different from those for subsistence farms, a joint estimation of the model for these two groups of farms might have caused biased estimates.

${ }^{6}$ The farm responses refer to the situation in 2009, 2008, 2005 and also the year prior to metal silo acquisition, which is individual for each farm-adopter. Both periods, from 2009 to 2010 and from 2008 to 2010, were too short to form a sufficiently large sub-sample of farm-adopters. Accordingly, the period from 2005 to 2009 was the only available option for obtaining a sufficiently large sub-sample and also for using the data corresponding to the same reference period for all farms.
} 
as a two-stage process: first, the household has to decide to invest or not invest; second, if the decision is made to invest, it must decide how much to invest. To this end, the so-called double-hurdle model was employed (Cragg 1971; Aramyan et al. 2007).

According to the double-hurdle model, the households' investment decisions can be formulated as follows:

$\mathbf{i}_{j}=\left\{\begin{array}{lll}\mathbf{i}_{j}^{*} & \text { if } & \mathbf{i}_{j}^{*} \geq 0 \text { and } d_{j}=1 \\ 0 & \text { if } & \mathbf{i}_{j}^{*} \leq 0 \text { and } d_{j}=0\end{array}\right.$

where $\mathbf{i}_{j}$ is the observed level of investment (i.e. storage capacity of the metal silo(s) acquired by a household), $\mathbf{d}_{j}$ is a binary variable describing the decision to invest or not, and $j$ is the household index and $\mathbf{i}^{*}{ }_{j}$ is the latent value of the investment volume.

Cragg's model consists of two regressions: a binary choice model is estimated in the first step, while the second step involves the estimation of a truncated regression model, viz:

$1^{\text {st }}$ step : $\mathbf{d}_{j}=\varphi^{\prime} \mathbf{z}_{j}+\theta_{j}$

$2^{\text {nd }}$ step $: \mathbf{i}_{j}^{*}=\beta^{\prime} \mathbf{x}_{j}+\varepsilon_{j}$

where $\theta_{j} \sim \mathrm{N}(0,1)$ and $\varepsilon_{j} \sim \mathrm{N}\left(0, \sigma_{\varepsilon}^{2}\right)$. Vectors $\mathbf{z}_{\mathbf{j}}$ and $\mathbf{x}_{\mathbf{j}}$ are the vectors of explanatory variables in binominal and truncated regression models, respectively.

Accordingly, in our empirical analysis we employed two dependent variables: a binary variable signaling whether or not a particular household acquired a metal silo in the period 2005 to 2009, and a further variable which represents the capacity of the respective metal silo(s). ${ }^{7}$ The vector of explanatory variables consists of different socio-economic characteristics of the sample households and is summarized in Table 8 (Appendix).

\section{Modeling impact of metal silo adoption}

The impact of using metal silos was investigated by focusing on three main aspects: a) food security; b) farmers' (and their families') well-being; and c) sales of maize. We employed linear regression models to assess how the metal silo adoption influenced food security and sales of maize.

Food security To assess differences between silo users and non-users with regard to food security, farmers were asked

\footnotetext{
${ }_{7}^{7}$ In the truncated regression, we used the Box-Cox transformation of the dependent variable.
}

how many months they had to buy (i.e. in addition to their own production) maize and beans. These questions covered the years 2008 and 2009. The average value of both years was used in the subsequent analyses. The investigated hypothesis is that silo users need to buy less staple grains from the market and can use their own production due to better storage capacity (Hermann 1991; Coulter et al. 1995; Gladstone et al. 2002). In a first step, empirical density functions of users and non-users are presented for each of the four countries (Guatemala, El Salvador, Honduras, Nicaragua). Because maize and bean production and consumption differ across these countries, we used a regression analysis to test if silo users in general needed to buy less maize and beans. ${ }^{8}$ Since the dependent variable is censored (by 0 from the left and 12 from the right), we used a tobit model, in which the numbers of months farms needed to buy maize and beans $\left(\right.$ Month $\left._{C}\right)$ are regressed against dummy variables for countries $\left(D_{\text {Country }}\right.$, Guatemala was chosen as reference category), for silo non-use (the use of silos is the reference category), as well as interaction terms between both dummy variables, where $\beta_{0}$ is the regression intercept:

$$
\begin{aligned}
\text { Month }_{C}= & \beta_{0}+\beta_{1} D_{\text {Non-User }}+\beta_{2} D_{\text {Country }} \\
& +\beta_{3} D_{\text {Non-User }} * D_{\text {Country. }} .
\end{aligned}
$$

Livelihoods To assess the impact of metal silos on noneconomic factors (e.g. health, gender and education issues), as well as on factors that are difficult to quantify (e.g. income), farmers were asked how their situation changed from 2005 to 2009 with regard to the following variables: the family's food situation; the family's income situation; the workload of women; children's health situation, and the children's education situation. Thus, the questions covered aspects from various important fields, i.e. improvements in economic status, food security, gender and children's situation. The answer scale ranged from 1 (high improvement) to 5 (severe worsening), while 3 indicated no change. Category 6 was used if the interviewee indicated 'I don't know'. We tested the hypotheses that silo users faced better economic and social development. This was motivated by the fact that silo adoption allows adopters to generate more income and to reduce their workload, as well as that silo users are more resilient to certain shocks (e.g. price fluctuations or bad harvests). In a first step, cross tables and Pearson Chi-Square tests were used to identify whether significant differences between

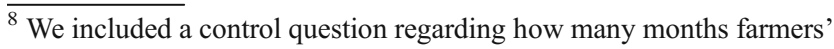
own production of maize and beans was sufficient for family food provision. This variable confirmed the presented results.
} 
users and non-users existed. In a second step, regression analyses were also used to consider country-specific effects (and interaction terms) following the Tobit regression approach described in Equation 4.

Sales of production We expected differences in the sale of stored grain and grain that is not stored (but sold immediately after harvest) with regard to the timing and location of sales as well as with regard to the distribution channel used. These differences were also expected to cause variation in the grain prices received for different storage technologies. The analyses presented in this section are focused on maize because it is the most important crop for the households interviewed.

To investigate whether the location of maize selling was affected by storage technology, the questionnaire included a question asking where maize was sold. The answer categories were as follows: on (one's own) farm; in the village; on the road; in the district town; others. Following the same structure, to whom the maize was sold was also asked. More specifically, the following answer categories were used: intermediates; retailers; super markets; farmers' organizations; direct sales to consumers; others. Furthermore, farmers indicated in which month they sold most of the maize and what price they received, on average. These questions were asked separately for the different categories of maize storage, i.e. for i) maize that is not stored; ii) maize stored in metal silos; and iii) maize stored in other storage systems.

For maize that is sold mainly directly after harvest, no difference between metal silo users and non-users was expected regarding the selling location and time, purchaser and price. In contrast, we expected differences between maize that is not stored and stored maize, because maize storage enables farmers to decide tactically where, when and at what price to sell their maize. Moreover, we expected that maize stored in metal silos could be kept longer than traditionally stored maize. Thus, the selling time as well as the price was expected to differ between these storage types. In order to test these hypotheses, we used cross tables and Pearson chi-square tests. In addition, group comparisons were conducted using the Mann-Whitney test. To test if maize prices from different storage systems lead to different prices, we used a regression analysis that also accounts for country-specific price differences:

Price $=\beta_{0}+\beta_{1} D_{\text {Storage Type }}+\beta_{2} D_{\text {Country }}$.

The dummy variable for the storage type ( $\left.D_{\text {Storage Type }}\right)$ used maize that is not stored as a reference category, while Guatemala was used as a reference category for the country dummy $\left(D_{\text {Country }}\right)$. Note that price data was only indicated by some farms, and interaction terms were thus not considered due to the lack of freedom in specific category combinations. All prices were given in local currencies and were converted into USD/qq in the results presented.

\section{Results}

Investment decision analysis

Table 2 summarizes the estimation results of the doublehurdle model for three of the countries considered in this part of the analysis, i.e. Guatemala, Honduras and Nicaragua. We completed model estimations for the whole subsample, i.e. considering all three countries, and separately for Guatemala and Honduras. As the number of relevant user-households for Nicaragua was rather small, we did not estimate the double-hurdle model for it separately. Additionally, as several farm characteristics exhibited a substantial degree of correlation, we did not estimate the model employing all relevant farm characteristics, but only those which showed a low degree of correlation among each other and which scored significant parameter estimates. ${ }^{9}$

The first step model estimates (i.e. estimates of the logistic regression model) for three countries showed that the decision to invest varied significantly across countries. ${ }^{10}$ In particular, the adoption of metal silos has been more extensive in Guatemala (the reference country) than in Honduras and Nicaragua in recent years. On the one hand, this might be related to dynamics of the metal-silo adoption in single countries. On the other hand, the adoption rate might be strongly influenced by governmental policies. Considering that more governmental efforts have been made to disseminate metal silos in Guatemala, our finding is indeed in line with the empirical evidence.

Furthermore, according to our estimates, significant differences in investment behavior existed regarding the age of the farm head, land ownership, completion of a training course, extent of maize self-sufficiency (calculated in months a household can cover its maize consumption by stored maize) and use of an alternative storage capacity such as metallic or plastic barrels, conical metal silos, etc. In particular, the estimation results showed that the probability of adoption declined with the age of the household head. This result is consistent with theoretical expectations (Rogers 2003) and findings of other empirical studies for both developing as well as developed countries (Barham et al. 2004; Ersado et al. 2004), suggesting that older people are more reserved regarding the introduction and acceptance of

\footnotetext{
${ }^{9}$ For example, several farm characteristics representing farm size, e.g. crop land, number of employees, etc., had a rather high correlation with the household maize self-sufficiency indicator.

${ }^{10}$ This result might, however, be related to the sample composition in this part of the analysis, in particular the share of user-households in the total number of households were substantially lower for Honduras and Nicaragua than for Guatemala. If this composition of the subsamples corresponded well to the real situation, then our finding is correct. Conversely, if the sample composition did not represent the actual stratification of the farmers, then this estimation result was biased due to inappropriate sampling.
} 
Table 2 Estimates of double hurdle model

\begin{tabular}{|c|c|c|c|}
\hline Variables & All 3 countries & Guatemala & Honduras \\
\hline \multicolumn{4}{|l|}{ 1. step } \\
\hline dummy Honduras & $-1.03 * * *$ & - & - \\
\hline dummy Nicaragua & $-1.15^{* * *}$ & - & - \\
\hline age & $-0.02 *$ & - & $-0.11^{*}$ \\
\hline $\operatorname{age}^{\wedge} 2$ & - & - & 0.00 \\
\hline ownership & $0.13 * *$ & - & $0.21 * *$ \\
\hline dummy training & $0.62 * * *$ & $0.74 * *$ & - \\
\hline maize self-sufficiency & $0.19 * * *$ & $0.24 * * *$ & $0.20 * *$ \\
\hline dummy altern. storage & $-0.51 * *$ & $-1.05 * * *$ & - \\
\hline dummy coffee & - & $2.11^{* *}$ & - \\
\hline constant & $-4.24 * * *$ & $-2.95 * * *$ & -1.23 \\
\hline Number of observations & 566 & 241 & 212 \\
\hline $\mathrm{R} 2$ & 0.10 & 0.11 & 0.08 \\
\hline LR chi2 & $70.89 * * *$ & $37.50 * * *$ & $16.04 * * *$ \\
\hline \multicolumn{4}{|l|}{ 2. step } \\
\hline dummy Honduras & $0.35^{* * *}$ & - & - \\
\hline dummy Nicaragua & 0.12 & - & - \\
\hline age & - & - & $0.01 * * *$ \\
\hline crop area & - & - & $0.06^{* *}$ \\
\hline dummy electricity & - & - & $0.31^{* * *}$ \\
\hline dummy subsidy & - & $0.15^{*}$ & - \\
\hline constant & $3.13^{* * *}$ & $2.56^{* * *}$ & $2.15^{* * *}$ \\
\hline Number of observations & 165 & 101 & 43 \\
\hline Wald chi2 & $12.09 * * *$ & $2.80 *$ & $20.58 * * *$ \\
\hline
\end{tabular}

$*, * *, * * *$ denote statistical significance at the $10 \%, 5 \%$ and $1 \%$ level, respectively.

Source: authors' estimates.

innovations due to declining cognitive and learning abilities. The possession of an alternative storage system also diminishes the probability of metal silo adoption. This result is very rational-a household's need for storage capacity declines if it already possesses an acceptable alternative storage system (e.g. metal or plastic barrels, conical silos).

Though we did not obtain a significant parameter estimate for the variable characterizing the household head's education, ${ }^{11}$ the variable 'training' (access to training and advisory services for grain production) had a highly significant positive parameter estimate. The latter suggests that knowledge of production technology seems to spark the household's interest in metal silo acquisition. In our view, this result might be explained in two ways. First, training allows farmers to obtain new knowledge and thus become

\footnotetext{
${ }^{11}$ As can be seen from Table 8 in the Appendix, educational background does not vary sufficiently across household heads; most household heads are alphabetized or have completed primary school. This low variation in educational background can explain insignificant parameter estimates for this variable.
}

more aware of possibilities for more efficient utilization of their resources as well as farm organization. Second, training courses present an important communication channel for disseminating information about new technological solutions available on the market, and therefore play an important role in improving farmers' access to relevant markets and production factors.

A larger share of owned land in farm cropland also had a significant impact on the investment decision. On the one hand, farms that possessed a larger portion of their cropland were wealthier and thus might more easily be able to afford a metal silo than less wealthy farms. ${ }^{12}$ On the other hand, they might also be more eager to invest in their farm in general, as they have less uncertainty regarding their land property rights, as well as a lower extent of agency costs due to potential information asymmetries between the land owner and tenant.

Finally, the probability of metal silo adoption increased with a household's maize self-sufficiency. This result is in line with the empirical evidence provided by other studies (e.g. Hermann 1991), in particular farms with lower levels of self-sufficiency often did not produce enough maize to fill a metal silo. Hence, metal silos present an effective instrument primarily for households with higher levels of self-sufficiency, while other policy instruments might be more effective for households with lower self-sufficiency levels. In particular, for the latter group of farms, instruments aimed at an increase of productivity through access to more advanced production technologies might trigger a more significant shift in food security and well-being.

The separate estimation of the logistic regression models for Guatemala and Honduras shows that different socioeconomic characteristics determine the adoption decision in these two countries. Whereas in Guatemala the decision to acquire a metal silo was influenced significantly by the completion of a training course and the use of an alternative storage system, the main determinants of silo adoption in Honduras were age and the extent of land ownership. The only variable which obtained a significant parameter estimate for both countries was maize self-sufficiency.

The second-step estimates (i.e. the truncated regression model estimates) also suggested the presence of significant differences in investment behavior of farms in the different countries. Though none of the farm characteristics considered obtained a significant parameter estimate in the pooled truncated regression model, the overall significance of the model was high, which obviously pertains to the usage of the country dummies. In addition, the estimation results indicated that the investment extent is significantly higher in Honduras, i.e. the farms in this country invested in larger

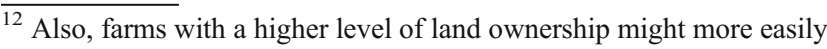
gain access to credit for buying a silo, as they can use their own land as collateral.
} 
metal silos. This result presumably is related to the fact that farms in Honduras are on average larger than in Guatemala, and compared to farms in Nicaragua specialize more in maize that requires larger storage capacity than beans.

The extent of investment in Guatemala was found to vary only subject to the provision of governmental subsidy, i.e. farms that received a subsidy had a tendency to buy an additional silo. The estimates of the model for Honduras showed that the extent of adoption (i.e. the storage volume) depended significantly on the age of the household head. However, in contrast to the first-step model estimates, the parameter estimate for the age variable had a positive sign in the second-step model. Still, the results of the first- and second-step model estimates did not contradict each other. The first-step estimates showed that in general, adopters were younger than non-adopters. The second-step estimation results indicated that among the adopters, older farmers tended to acquire larger storage capacities. Older farmers usually had larger families than their younger counterparts, and thus required more storage capacity. Our results also showed that larger metal silos were usually requested by farms with a larger crop area. Access to electricity, which can be used as a proxy for infrastructure development, had a significant impact on investment volume; this suggests that farms with better access to markets, i.e. lower transaction costs, invested significantly more.

\section{Impact assessment}

\section{Food security}

Figure 1 shows the empirical density functions of months per year the surveyed farm-households had to buy maize from the market. All interviewed farmers produced maize and therefore had little or no need to buy additional maize. For all countries, we found that metal silo users needed to buy maize from the market in fewer months.

The results for beans, which are presented in Fig. 2, contrast to our findings for maize. It shows that in all countries, two groups of producers exist that either produce almost enough for their own consumption, or buy most of their beans from the market. The second group of farmers is well represented in Guatemala and El Salvador, while farms in Nicaragua are rather more focused on their own bean production. The strongest differences between metal silo users and non-users are indicated for El Salvador, where users tend to rely much less on their own bean production and buy more beans from the market.

The results of the Tobit model estimation presented in Table 3 show that non-users needed to buy maize in (significantly) more months than metal silo users. Country effects showed that households in El Salvador needed to buy (on average) less maize and beans (also for Nicaragua) than in Guatemala, which is the reference category in our analysis. For the number of months when beans were purchased, no general impact of silo use was found. However, the significant interaction effect of the dummy for silo nonuse and the dummy for El Salvador shows that silo users in this country needed to buy beans in fewer months (compared with those in Guatemala). The latter result is furthermore underpinned by the empirical density function presented in Fig. 2, where the largest difference between metal silo users and non-users was indicated for El Salvador. ${ }^{13}$

For the interpretation of the results presented on the relationship between metal silo use and food security, it is important to take into consideration that metal silo users are usually characterized by a higher degree of self-sufficiency (cf. section 4.1). Thus, silo users already relied less on buying maize and beans before they acquired the metal silo. Therefore, the results presented were caused not only by the effect of the metal silo but also by higher general production levels of these farms.

\section{Farmers' well-being}

Cross tables for all answer categories (i.e. on developments of the family's food situation, the family's income, the workload of women, children's health and education) showed significant differences between metal silo users and non-users (data not presented). In order to test whether metal silo users tend to assess their situation more positively than non-users, regression analysis was used. Table 4 shows the results of the regression analysis on the assessment of these economic and social aspects of well-being. Note that answer scales ranged from 1 (high improvement) to 5 (severe worsening), while 3 indicated no change. Answers that indicated "I don't know" were not considered in the regression analysis. ${ }^{14}$ The results showed that in all categories, households from Guatemala (reference category) had the smallest values, i.e. the best situation, because dummies for all other countries were significantly positive. More importantly, non-users had significantly higher (i.e. worse) responses compared to metal silo users. Thus, metal silo users assessed economic and social development more positively.

We also asked farmers to indicate the main reason for positive developments in their food security and income situation in an open question. Farmers frequently mentioned increased off-farm employment as a contributing factor for

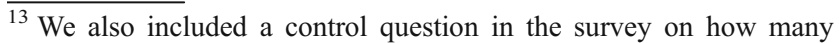
months households could cover their consumption from stored grain (maize and beans) production. These results confirmed the presented results: metal silo users indicated a higher degree of self-sufficiency.

${ }^{14}$ Furthermore, missing values were generated if the question did not apply to certain families that were interviewed (e.g. they had no children).
} 
Fig. 1 Months of the year the surveyed farm-households had to buy maize from the market. Source: authors' estimates

Fig. 2 Months of the year the surveyed farm-households had to buy beans from the market. Source: authors' estimates

\section{Guatemala}

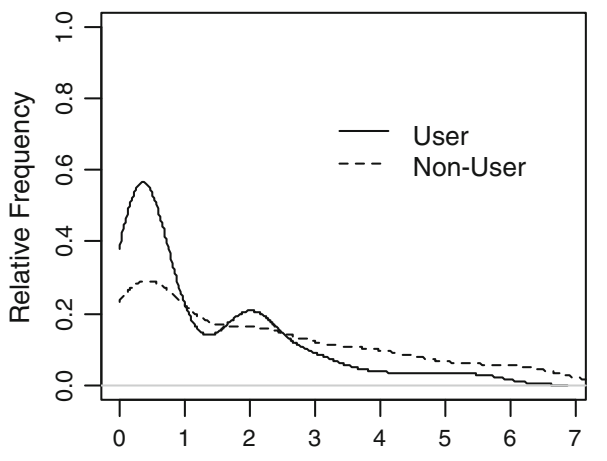

Months of Maize Buying - 2008/2009 Average

Honduras

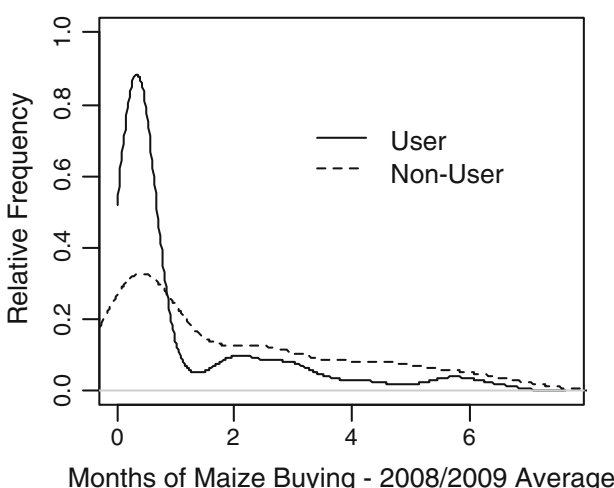

Months of Maize Buying - 2008/2009 Average

\section{Guatemala}

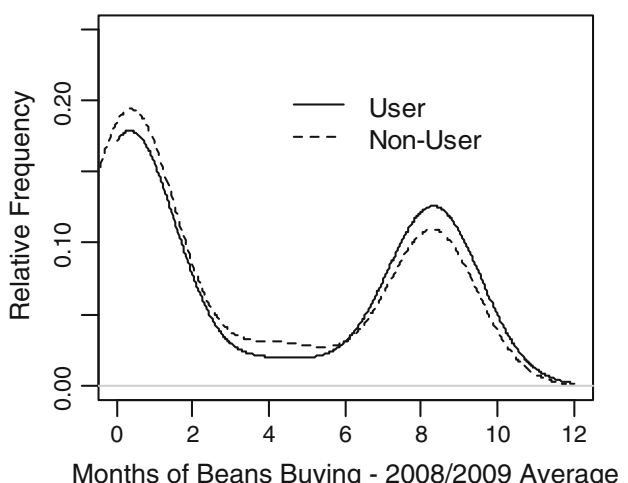

Honduras

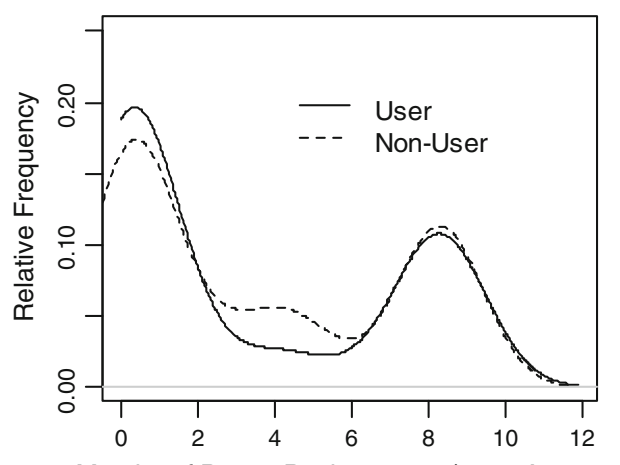

Months of Beans Buying - 2008/2009 Average
El Salvador

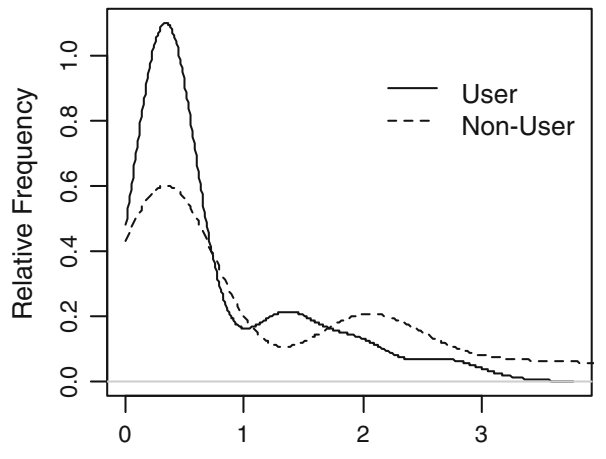

Months of Maize Buying - 2008/2009 Average

Nicaragua

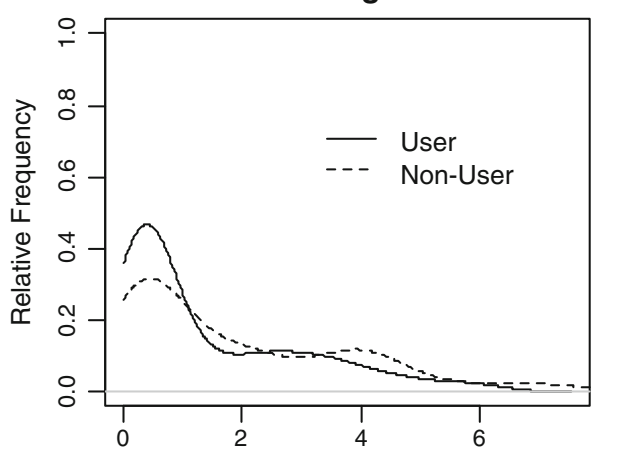

Months of Maize Buying - 2008/2009 Average

El Salvador

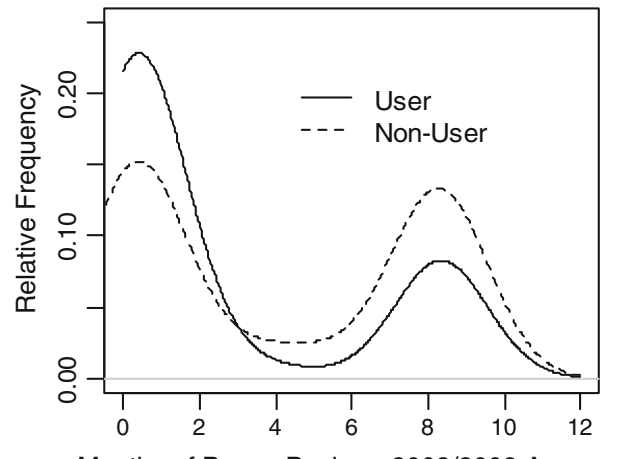

Months of Beans Buying - 2008/2009 Average

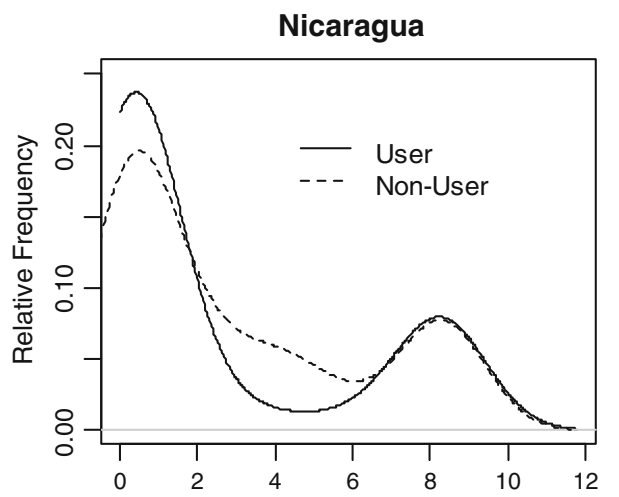

Months of Beans Buying - 2008/2009 Average 
Table 3 Tobit regression analysis on the determinants of number of months when additional food buying was necessary (average values for 2008/2009)

${ }^{\mathrm{a} C}$ Country specific effects are evaluated against Guatemala as reference category.

$* *$ and $* * *$ denote significance at the $5 \%$ and $1 \%$ levels, respectively

Source: authors' estimates

\begin{tabular}{lll}
\hline & $\begin{array}{l}\text { Number of months when } \\
\text { maize has to be bought }\end{array}$ & $\begin{array}{l}\text { Number of months when } \\
\text { beans has to be bought }\end{array}$ \\
\hline Intercept & $-0.23^{* * *}$ & $3.69 * * *$ \\
Dummy Non-User (vs. User) & $0.44 * * *$ & -0.35 (n.s.) \\
Dummy El Salvador $^{\mathrm{a}}$ & $-0.42^{* * *}$ & $-1.16^{* * *}$ \\
Dummy Honduras $^{\mathrm{a}}$ & $-0.27^{* *}$ & -0.43 (n.s.) \\
Dummy Nicaragua $^{\mathrm{a}}$ & 0.02 (n.s.) & $-1.20 * * *$ \\
Dummy Non-User x Dummy El Salvador $^{\mathrm{a}}$ & -0.13 (n.s.) & $1.90 * * *$ \\
Dummy Non-User x Dummy Honduras $^{\mathrm{a}}$ & 0.14 (n.s.) & 0.70 (n.s.) \\
Dummy Non-User x Dummy Nicaragua $^{\mathrm{a}}$ & -0.17 (n.s.) & 0.80 (n.s.) \\
Observations & 1195 & 1195 \\
Log-likelihood & -1534 & -3212 \\
\hline
\end{tabular}

improved food security and income. The reduction in workload for women is explained by the change in postharvest operation, which also requires a different division of labor. Due to the need for shelling, i.e. removing the kernels from the cob and drying all the grain at once for filling the silo, men are more actively engaged in these operations and sometimes use machines, thereby considerably reducing the workload of women. In addition, the removal of grain from the silo for daily consumption, mainly done by women, is more convenient compared to the traditional method of daily shelling.

\section{Selling of maize}

Selling of maize immediately after harvest was done mainly at the farm and in the village and, as expected, there was no significant difference in the numbers of respondents who used these two locations between users and non-users of metal silos (Table 5). More than $75 \%$ of all farmers who sold their maize immediately after harvest did so to intermediaries, while the rest was mainly sold directly to consumers (data not shown).

In order to compare the selling location and purchaser of stored maize and maize that had not been stored, we focused our analysis on metal silo users. ${ }^{15}$ Among the users, details of maize sold that was not stored were reported from 225 farms, while 123 observations were available for maize stored in metal silos. Details on selling maize stored in other systems were reported by 89 farms. Table 6 shows relative frequencies (in \%) for the selling location, purchaser, and main month of selling. Stored maize was sold in the village (67\%) mainly directly to consumers while non-stored maize was sold on the farm (52\%) mainly to intermediaries (76\%). With regard to the selling location and purchaser of maize stored in other systems, these ranged between maize that is not stored and maize stored in metal silos. It was mainly sold in the

\footnotetext{
$\overline{15}$ This restriction on adopters is necessary to ensure that we compare farms at the same level of consumption and with the same selling patterns.
}

village or the district's town, but less often sold directly to the consumer compared to maize stored in metal silos.

The time of selling varied significantly: the main selling period for maize that is not stored was directly after harvest, $74 \%$ of the farmers indicating the period from November to January. In contrast, maize stored in metal silos was mainly sold from March until July, the most critical period before the new harvest, when selling prices were highest. Maize stored in other systems was usually sold after maize that is not stored but before maize that had been stored in metal silos

In order to compare the prices received for maize from different storage systems, we used observations from all 1,195 sample farms. Figure 3 shows box plots of price levels, where all values were converted to USD/qq; it shows that stored maize generates, in general, higher prices than maize that has not been stored (and sold immediately after harvest). Moreover, prices for maize stored in metal silos seem to be on average higher than for maize from other storage systems.

In order also to account for different price levels in the four countries considered, we conducted a regression analysis that used dummy variables for countries and storage system terms (see Equation 5). Maize price levels in El Salvador and Nicaragua were lower than in Honduras and Guatemala (the reference category of this analysis; Table 7). Moreover, if these country-specific effects are considered, maize stored in metal silos led to an average price markup of $1.85 \mathrm{USD} / \mathrm{qq}$, while maize stored in other storage systems generates a price markup of $1.46 \mathrm{USD} / \mathrm{qq}$ compared to maize that has not been stored.

\section{Discussion}

Postharvest losses in yield are a major factor that negatively affects household food security in rural areas of Central America. From 1983 to 2003, SDC implemented the Postcosecha Program, which aimed at reducing smallholder 
Table 4 Regression analysis on the assessment of economic and social aspects of family well-being

\begin{tabular}{|c|c|c|c|c|c|}
\hline & Food Aspects & Family Income & Women Workload & Children's Health & Children's Education \\
\hline Intercept & $2.27 * * *$ & $2.46 * * *$ & $2.70 * * *$ & $2.41 * * *$ & $2.48 * * *$ \\
\hline Dummy Non-User (vs. User) & $0.50 * * *$ & $0.41 * * *$ & $0.28 * * *$ & $0.28 * * *$ & $0.18 * *$ \\
\hline Dummy El Salvador ${ }^{\mathrm{a}}$ & $0.46^{* * *}$ & $0.37 * * *$ & $0.33 * * *$ & $0.26 * * *$ & $0.20 * *$ \\
\hline Dummy Honduras ${ }^{\mathrm{a}}$ & $0.25 * * *$ & $0.18 * *$ & $0.19 * * *$ & $0.28 * * *$ & 0.11 (n.s.) \\
\hline Dummy Nicaragua $^{\mathrm{a}}$ & $0.78 * * *$ & $0.57 * * *$ & $0.23 * * *$ & $0.57 * * *$ & $0.22 * * *$ \\
\hline Dummy Non-User x Dummy El Salvador ${ }^{\mathrm{a}}$ & $-0.42 * * *$ & -0.25 (n.s.) & $-0.30 * * *$ & $-0.19 * *$ & 0.02 (n.s.) \\
\hline Dummy Non-User x Dummy Honduras ${ }^{\mathrm{a}}$ & $-0.28 * *$ & $-0.14 * *$ & $-0.17 * *$ & $-0.18 * *$ & -0.11 (n.s.) \\
\hline Dummy Non-User x Dummy Nicaragua ${ }^{a}$ & $-0.41 * * *$ & $-0.34 * * *$ & $-0.26 * * *$ & $-0.33 * * *$ & $-0.23 * *$ \\
\hline Degrees of Freedom & 1176 & 1163 & 1080 & 1150 & 1099 \\
\hline Adjusted R2 & 0.11 & 0.07 & 0.03 & 0.06 & 0.02 \\
\hline
\end{tabular}

${ }^{a}$ Country-specific effects are evaluated against Guatemala as reference category.

$* *$ and $* * *$ denote significance at the $5 \%$ and $1 \%$ levels, respectively

Source: authors' estimates.

farmers' postharvest losses by supporting the manufacture and use of metal silos. This study evaluated determinants of the adoption and impact of the use of metal silos on the food security and well-being of rural households in El Salvador, Guatemala, Honduras and Nicaragua from 2005 to 2009.

Our results showed that both the demand for metal silos and the impact of their adoption was different across the four countries. The highest demand, as well as the highest impact of the adoption of metal silos from 2005-2009 was observable in Guatemala, suggesting that this country has found an effective policy for metal silo dissemination. In contrast to the other three countries, where the government might spasmodically disseminate metal silos free of charge, e.g. prior to an election, the government of Guatemala provides regular support in the form of a subsidy to smallholder farmers interested in acquiring metal silos. Additionally, farmers from Guatemala more often reported that they had access to extension services in the form of training in subjects relevant to grain production.

Table 5 Location of selling for maize that is not stored

\begin{tabular}{llll}
\hline & Users & Non-Users & Row Total \\
\hline Farm & 116 & 111 & 227 \\
Village & 87 & 87 & 174 \\
Road & 8 & 1 & 9 \\
District town & 10 & 8 & 18 \\
Other & 4 & 5 & 9 \\
Column Total & 225 & 212 & 437 \\
$\begin{array}{l}\text { Pearson's Chi-squared } \\
\text { test statistic }\end{array}$ & 5.50 (n.s.) & & \\
\hline
\end{tabular}

a several households did not indicate sufficient details on maize selling and the total number of observations decreased from 1,195 to 437 .

Source: authors' estimates.
Furthermore, our results indicated that the desire for household self-sufficiency in maize was an important factor in explaining farmers' demand for metal silos. These would only be fully effective if the farmer had the potential to produce enough maize to be self-sufficient, alternative strategies for improving productivity might be more appropriate for subsistence farms with lower levels of potential self-sufficiency. Besides, the adoption of metal silos was influenced by a group of socio-economic characteristics of the households which included age of the head of the household, land ownership, access to extension services and quality of basic infrastructure.

We found that, compared to the non-adopters, the adopter households experienced a significantly higher improvement in their well-being from 2005 to 2009. For instance, as adopters had to buy less food and had improved the marketing of their harvests, they had greater financial freedom. This resulted in better health and education of their children and is likely to have direct spillovers (and multiplier effects) on future generations, ensuring sustainable long-term improvements. Furthermore, silos reduced gender inequalities by reducing women's workload owing to the elimination of the daily shelling. Therefore, the promotion of metal silos seems to provide a path for sustainable social and economic development, which should be considered when evaluating policy. Households were also asked to assess the development of their food security in this period; metal silo users indicated much better development than non-users.

Our results on maize-selling patterns showed that metal silo users are much more flexible regarding when and where they sell their harvest. Primarily, this provides higher economic returns for the users. However, this also has an indirect effect on other households. Because the supply of food from local producers is not limited to harvest periods, price peaks on local markets are expected to decline. Thus, this storage technique is expected to contribute to less variable prices and more affordable food for poor households. 
Table 6 Analysis for silo users: stored maize vs. maize that is not stored-location and time of selling and purchaser
*** denotes significance at the $1 \%$ level

Source: authors' estimates.

\begin{tabular}{|c|c|c|c|}
\hline & $\begin{array}{l}\text { Maize that is not } \\
\text { stored }(N=225)\end{array}$ & $\begin{array}{l}\text { Metal Silo Stored } \\
\text { Maize }(N=123)\end{array}$ & $\begin{array}{l}\text { Maize stored in other } \\
\text { system }(N=89)\end{array}$ \\
\hline \multicolumn{4}{|l|}{ Selling Location } \\
\hline Farm & $52 \%$ & $24 \%$ & $24 \%$ \\
\hline Village & $39 \%$ & $67 \%$ & $57 \%$ \\
\hline Road & $4 \%$ & $1 \%$ & $1 \%$ \\
\hline District town & $4 \%$ & $7 \%$ & $11 \%$ \\
\hline Other & $2 \%$ & $2 \%$ & $7 \%$ \\
\hline Pearson's Chi-squared test statistic & $49.26^{* * *}$ & & \\
\hline \multicolumn{4}{|l|}{ Purchaser } \\
\hline Intermediaries & $76 \%$ & $41 \%$ & $54 \%$ \\
\hline $\begin{array}{l}\text { Commercial house, Supermarket, } \\
\text { and Farmers' Organization }\end{array}$ & $0 \%$ & $2 \%$ & $5 \%$ \\
\hline Direct to consumer & $20 \%$ & $50 \%$ & $34 \%$ \\
\hline Others & $3 \%$ & $7 \%$ & $7 \%$ \\
\hline Pearson's Chi-squared test statistic & $56.12 * * *$ & & \\
\hline \multicolumn{4}{|l|}{ Month of Selling } \\
\hline August-October & $12 \%$ & $7 \%$ & $14 \%$ \\
\hline November-February & $79 \%$ & $20 \%$ & $36 \%$ \\
\hline March-July & $9 \%$ & $73 \%$ & $50 \%$ \\
\hline Pearson's Chi-squared test statistic & $302.85 * * *$ & & \\
\hline
\end{tabular}

The results of the analysis allow two important policy implications to be derived. First, more targeted policies are required. This aspect primarily concerns the design of policy instruments considering different household clusters. In particular, policy design should differentiate between the needs of and effective instruments for farms performing under and over the subsistence level. Additionally, as our results suggest that factors determining the adoption of an innovative technology might vary from country to country, when

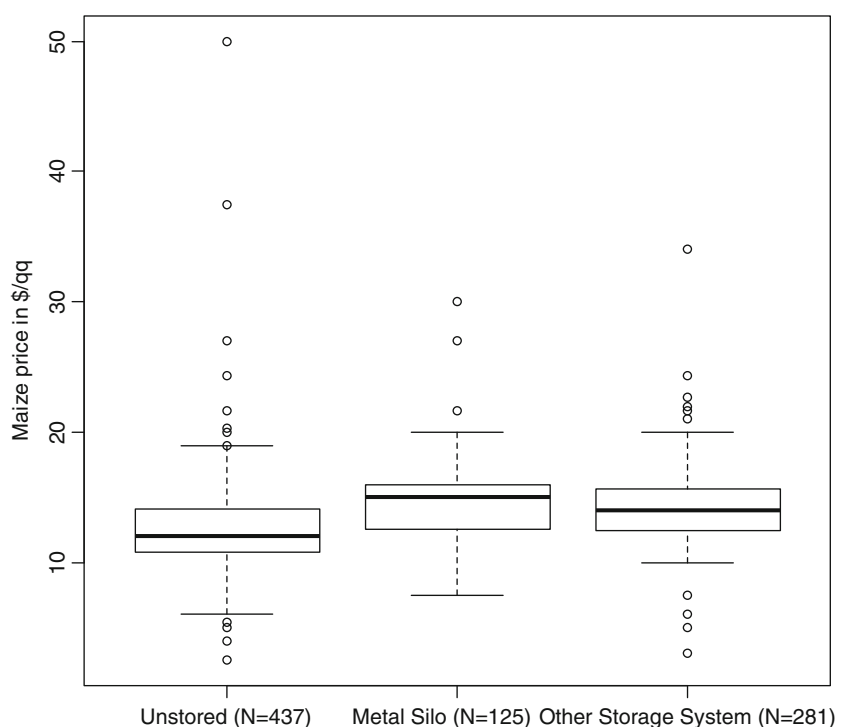

Fig. 3 Maize price by storage system. Source: authors' estimates developing policy instruments more attention should be paid to regional specifics and should incorporate a careful examination of the main needs and limitations to development in each country. The example of the subsidy model in Guatemala targeting poor rural households is interesting in this respect. Second, regarding the relatively low educational level of farmers, more efforts should be carried out to improve farmers' professional skills, as well as their access to and awareness of innovative technological solutions.

Table 7 Regression analysis: maize price for different storage systems Maize Price in $\mathrm{USD} / \mathrm{qq}$

Intercept $13.70 * * *$

Dummy Storage Metal Silo (vs. maize that is not $1.85 * * *$ stored)

Dummy Other Storage System (vs. maize that is $1.46 * * *$ not stored)

Dummy El Salvador ${ }^{\mathrm{a}} \quad-1.38 * * *$

Dummy Honduras $^{\mathrm{a}} \quad 0.54$ (n.s.)

Dummy Nicaragua $^{\mathrm{a}} \quad-2.75 * * *$

Degrees of Freedom 837

Adjusted R2 0.14

$* * *$ denotes significance at the $1 \%$ level

Source: authors' estimates.

${ }^{a}$ Country-specific effects are evaluated against Guatemala as the reference category. 
Open Access This article is distributed under the terms of the Creative Commons Attribution License which permits any use, distribution, and reproduction in any medium, provided the original author(s) and the source are credited.

\section{Appendix}

Table 8 Descriptive statistics of variables employed in the double hurdle model

\begin{tabular}{|c|c|c|c|c|c|c|c|c|c|}
\hline \multirow[t]{2}{*}{ Variable } & \multirow[t]{2}{*}{ Description } & \multicolumn{4}{|c|}{165 metal silo users } & \multicolumn{4}{|c|}{401 non-users } \\
\hline & & Mean & S.D. & Min & Max & Mean & S.D. & Min & Max \\
\hline silosizesum & farm total metal silo storage capacity, quintals & 15.82 & 7.62 & 0 & 68 & 0.00 & 0.00 & 0 & 0 \\
\hline age & household head age, years & 44.09 & 14.53 & 18 & 86 & 45.13 & 14.04 & 18 & 82 \\
\hline education & $\begin{array}{l}\text { educational background ( } 1 \text { - none, } 5 \text { - professional education and } \\
\text { higher) }\end{array}$ & 2.43 & 0.98 & 1 & 5 & 2.45 & 1.01 & 1 & 5 \\
\hline dummy training & $\begin{array}{l}\text { 1, if the household head completed a course in a grain production } \\
\text { subject; } 0 \text { otherwise }\end{array}$ & 0.32 & 0.47 & 0 & 1 & 0.15 & 0.36 & 0 & 1 \\
\hline family size & number of family members & 5.27 & 2.46 & 1 & 13 & 5.14 & 2.26 & 1 & 14 \\
\hline $\begin{array}{l}\text { dummy off-farm } \\
\text { job }\end{array}$ & 1 , if one of the children left family to find an employment; 0 otherwise & 0.22 & 0.42 & 0 & 1 & 0.26 & 0.44 & 0 & 1 \\
\hline crop area & farm crop area, manzanas & 1.57 & 1.28 & 0.08 & 10 & 1.74 & 1.40 & 0.06 & 13 \\
\hline ownership & share of own land in farm crop area & 1.35 & 1.81 & 0 & 10 & 1.33 & 1.75 & 0 & 20 \\
\hline dummy workers & 1 , if the farm employs permanent or temporal workers; 0 otherwise & 0.49 & 0.50 & 0 & 1 & 0.49 & 0.50 & 0 & 1 \\
\hline dummy livestock & 1 , if the farm possesses livestock; 0 otherwise & 0.30 & 0.46 & 0 & 1 & 0.24 & 0.43 & 0 & 1 \\
\hline cattle & number of cattle & 0.58 & 1.30 & 0 & 6 & 0.74 & 3.34 & 0 & 50 \\
\hline pigs & number of pigs & 0.16 & 0.46 & 0 & 2 & 0.31 & 1.15 & 0 & 15 \\
\hline dummy coffee & 1 , if the farm has a coffee plantation; 0 otherwise & 0.07 & 0.25 & 0 & 1 & 0.05 & 0.22 & 0 & 1 \\
\hline $\begin{array}{l}\text { maize self- } \\
\text { sufficiency }\end{array}$ & $\begin{array}{l}\text { number of months covering the family demand in maize from stored } \\
\text { maize. }\end{array}$ & 10.92 & 2.09 & 3 & 12 & 9.64 & 3.13 & 0 & 12 \\
\hline $\begin{array}{l}\text { bean self- } \\
\text { sufficiency }\end{array}$ & $\begin{array}{l}\text { number of months covering the family demand in beans from stored } \\
\text { beans }\end{array}$ & 5.04 & 5.83 & 0 & 12 & 5.25 & 5.78 & 0 & 12 \\
\hline $\begin{array}{l}\text { dummy altern. } \\
\text { storage }\end{array}$ & 1 , if the farm possesses an alternative storage capacity; 0 otherwise & 0.18 & 0.39 & 0 & 1 & 0.22 & 0.42 & 0 & 1 \\
\hline dummy subsidy & $\begin{array}{l}\text { 1, if the farm obtained a subsidy when purchasing a metal silo; } 0 \\
\text { otherwise }\end{array}$ & 0.51 & 0.50 & 0 & 1 & 0.00 & 0.00 & 0 & 0 \\
\hline dummy electricity & 1 , if the farm has access to electricity; 0 otherwise & 0.70 & 0.46 & 0 & 1 & 0.50 & 0.50 & 0 & 1 \\
\hline
\end{tabular}

\section{References}

Abeleira, N., Pérez, O. C., Ferrer, J. G., Sánchez, E. G., \& Figueroa, H. H. (2008). Postharvest losses of common bean seed in a traditional storage system. Agricultura Técnica en México, 34(001), 91-100.

Aramyan, L., Oude Lansink, A., \& Verstegen, J. (2007). Factors underlying the investment decision in energy-saving systems in Dutch horticulture. Agricultural Systems, 94, 520-527.

Barham, B. L., Foltz, J. D., Jackson-Smith, D., \& Moon, S. (2004). The Dynamics of Agricultural Biotechnology Adoption: Lessons from series rBST Use in Wisconsin, 1994-2001. American Journal of Agricultural Economics, 86, 61-72.

Baumeister, E. (2010). Pequennos productores de granos basicos en Ameica Central. FAO-RUTA, pp. 38

Bravo, J. (2009). Metal silos and food security. Lessons learned from a successful Central American Post-Harvest Program, pp. 270

Coulter, J., Brüssel, J., \& Wright, M. (1995). Programa Postscosecha en Centroamerica: Evalucion de impacto y de la sostenibilidad. SDC, pp. 56
Cragg, J. G. (1971). Some statistical models for limited dependent variables with application to the demand for durable goods. Econometrica: 829-844

Ersado, L., Amacher, G., \& Alwang, J. (2004). Productivity and land enhancing technologies in northern ethiopia: health, public investments, and sequential adoption. American Journal of Agricultural Economics, 86, 321-331.

Florkowski, J., \& Xi-Lling, J. (1990). Simulating the impact of pecan storage technology on farm price and grower's income. Southern Journal of Agricultural Economics, 22(2), 217-222.

Gladstone, S., Astuias, L., \& Hruska, J. (2002). Estudio de adopción y de impactos de tecnologias Postscosecha. COSUDE, pp. 82

Hermann, H. (1991). Seguridad alimentaria.: comparación de impactos socio-eoconomicas en la tenencia del silo métalico versu sistema tradicional de almacenamiento. SDC, pp. 41

Hernández, M. (2008). Analisis de la evolucion de los precios de maiz, arroz trigo y de sus productos derivados en Guatemala: un studio de los impactos de los precios en el consume de estos cereals en la 
coyuntura actual. Infore final de investigacion de coyunctura. Universidad de San Carlos de Guatemala, pp. 33

Pérez, F., Barrios, J., \& Pavón, K. (2010). Responses to high world food prices. Nitlapan/IDS/ODI/DFID

Raboud, G., Narvaez, M., \& Sieber, J. (1984). Evaluacion de peridas post-produccion de maiz a nivel de pequeños y medianos productores en Honduras. COSUDE, pp. 18

Rogers, E. M. (2003). Diffusion of Innovations (5th ed.). New York: Free Press.

SDC (2008a). Metal Silos. Manual for manufacturing metal silos for grain storage. 2nd edn

SDC (2008b). Latin Brief. Central America: Fighting poverty with silos and job creation. www.postharvest.ch, October 07, 2009

SDC (2011). Five year ex-post impact study Postcosecha Program in Central America. Report prepared on behalf of the Swiss Agency for Development and Cooperation. Bern

Tefera, T., Kanampiu, F., Groote, H. D., Hellin, J., Mugo, S., Kimenju, S., et al. (2010). The metal silo: An effective grain storage technology for reducing post-harvest insect and pathogen losses in maize while improving smallholder farmers' food security in developing countries. Crop Protection, in press, 1-6

World Bank (2008). World Development Indicators. http://data. worldbank.org/indicator

Zappacosta, M. (2005). Honduras: Market profile for emergency food security assessments. World Food Program, United Nations

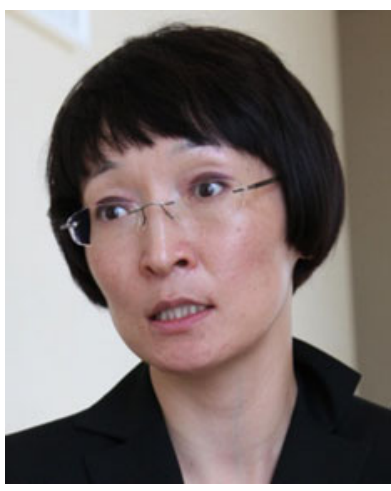

Raushan Bokusheva studied Agricultural Economics at the Moscow Timiryazev Agricultural Academy from 1987 to 1992 . In 1997 she obtained her $\mathrm{PhD}$ degree there in Economic Modeling. At present she is Senior Researcher and Lecturer in the Group "Agri-Food and AgriEnvironmental Economics" at the ETH Zurich. Before she joined ETH Zurich in 2007, she had worked for 6 years at the Leibniz Institute for Agricultural Development in Central and Eastern Europe (Halle, Germany). Her research is focuses on risk analysis, productivity analysis and analysis of investment behavior.

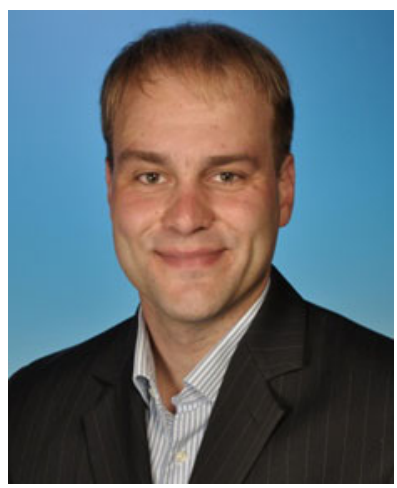

Robert Finger studied Economics at the European University Viadriana in Frankfurt (Oder), Germany. In 2009, he obtained a $\mathrm{PhD}$ in Agricultural Economics at the ETH Zurich, Switzerland, where he is currently Senior Researcher and Lecturer in the Group "Agri-Food and Agri-Environmental Economics". In his research, he focuses on risks in agriculture, climate change impacts and adaptation as well as on questions of water and innovations in agriculture.

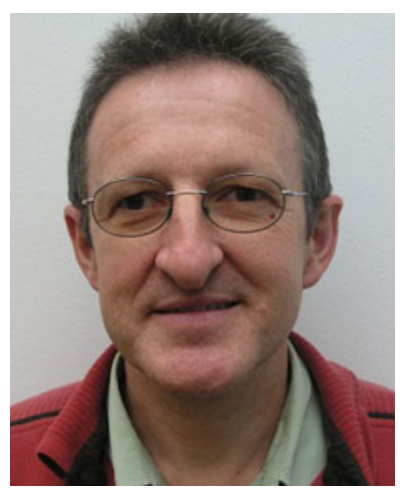

Martin Fischler studied Agronomy at the Swiss Federal Institute of Technology (ETH) in Zurich from 1983 to 1989 . In 1997 he also obtained his $\mathrm{PhD}$ degree there in natural sciences with field work conducted on soil fertility with the International Centre for Tropical Agriculture (CIAT) in Uganda. He then joined HELVETAS Swiss Intercooperation to work as advisor in two developing projects in Central America and Bolivia. Since 2005 he has been working at the head office as programme coordinator and senior advisor for sustainable agriculture and rural advisory services, focussing on food security, natural resource management, market development for smallholder farming systems, and impact assessments.

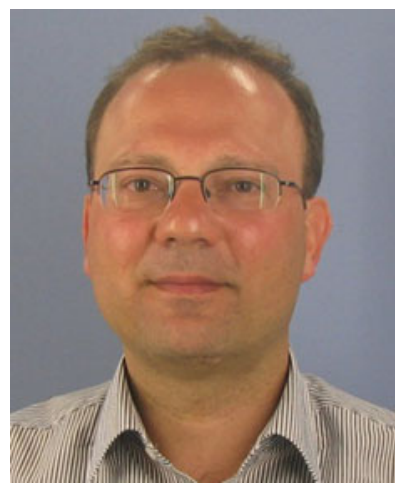

Robert Berlin holds a degree in Agronomy from the University of Applied Sciences Western Switzerland. In 1997 he obtained a Postgraduate Diploma in International Agriculture from Bern University of Applied Science. At present he is Agribusiness Manager at the Syngenta Foundation for Sustainable Agriculture in Basel. Before joining the Foundation in 2011, he worked for 9 years as adviser and Senior Programme Officer at the NGO Intercooperation in Switzerland, Central and South America, Sub-Saharan Africa, Eastern Europe and Asia. Previously, he worked for FAO in Nicaragua. His work focuses on smallholder farmers, productivity and access to markets.

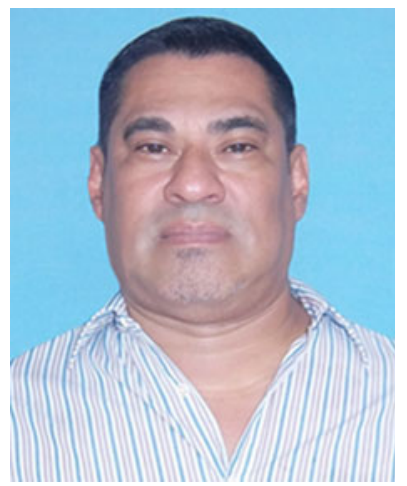

Yuri Marin studied agronomy with specialization in agricultural economics at the Chapingo Autonomous University, Mexico from 1982 to 1986 . In 2002 he obtained his Masters Degree in tropical agroforestry from the Tropical Agricultural Research and Higher Education Centre (CATIE), Costa Rica. Currently he works as senior researcher on agricultural technologies and natural resources at the Institute of Applied Research and Local Development (Nitlapan) at the Central American University (UCA) in Managua, Nicaragua. His research focuses on topics such as agricultural technology change and 
innovation, socio-economic and environmental evaluation of projects, and analysis of value chains and rural poverty.

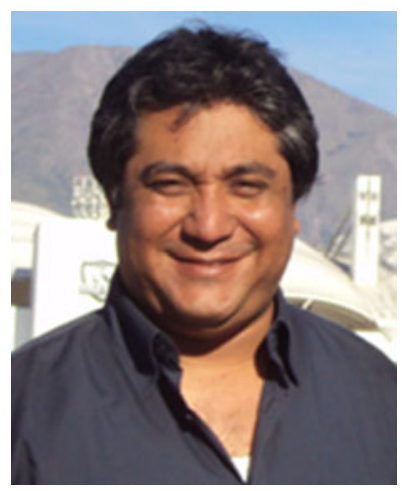

Francisco J. Perez earned his M.A. in International Development Studies from Ohio University. He worked in areas related to rural development and indigenous land rights in Guatemala. He has been a member of international teams with IFAD, WB, IABD, ODI and RUTA. His research expertise covers topics related to agricultural policy, technology, value chain analysis, and implications of economic liberalization in agricultural development.

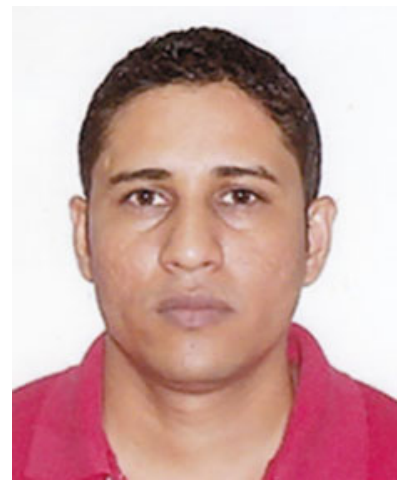

Francisco Paiz Salgado studied engineering in agricultural production systems in the Central American University (UCA) in Managua, Nicaragua from 1997 to 2001. In 1998, he was awarded the Title of Master in Local Development at the University of Extremadura, Spain. He currently serves as junior researcher at the Institute of Applied Research and Local Development (Nitlapan) at the UCA where he has been working for the last eight years on studies related to participatory evaluation of development programs, food safety, value chains, territorial dynamics and management of natural resources. In this work, he applies participatory techniques and programs such as SPSS and Nvivo UCINET. 